\title{
MEDIA DAN POLITIK CITRA DALAM POLITIK INDONESIA KONTEMPORER
}

\author{
Inri Inggrit Indrayani \\ Program Studi Ilmu Komunikasi, Universitas Kristen Petra Surabaya \\ Email: inri.inggrit@petra.ac.id
}

\begin{abstract}
The role of media in dinamics of Contemporary Indonesia Politic is slightly changing. Media control toward public opinion lets media become a tool for image creation and contestation in politic. The esence of politic have been reduced, on the other side the image of candidate become strategic isue beyond party program, vision and mision of the candidate. In political image, media change the candidate to be a package product adjusted to market taste instead of placing him as a political figure. Moreover, media represent constituent as political target market that can be influenced through public relations, marketing and ads strategies. Political image is also played by media within news, especially those which related to authorized power and capitalists. The win of candidate is determined by his soft skill in playing political image through the media.
\end{abstract}

Keywords: Media, political image, contemporary indonesia politics.

\section{PENDAHULUAN}

Its name is Public Opinion. It is held reverence. It settles everything. Some think it is the voice of God

(Mark Twain)

Satu fenomena menarik dalam pesta demokrasi yang terjadi sekitar dua periode terakhir ini di Indonesia, ialah maraknya iklan politik yang dibarengi dengan berbagai bentuk promosi kandidat politik di media. Fenomena ini semakin menguatkan argumentasi yang menyatakan adanya relasi yang erat antara media dan politik. Water Lippmann (dalam Brian McNair, 1999) mensinyalir munculnya terminologi "public opinion" dalam proses politik sejak beberapa dasawarsa yang lalu.

Pembentukan opini publik ini melibatkan banyak pihak sebagai penghubung antara kandidat politik dengan konstituennya, salah satunya ialah media yang selama ini diyakini sebagai the builder of public opinion. Brian McNair juga menekankan bahwa pada era saat ini politik mengalami metamorfosis. McNair menyebutnya dengan istilah era politik yang menggunakan media atau politics in the age of mediation.

Relasi media dan politik selama ini kenyataannya senantiasa dihadapkan dengan dilema. Dalam perspektif demokrasi, media diyakini sebagai fourth state yang berperan sebagai lembaga kontrol bagi pelaksanaan good corporate governance. Dalam konsep negara demokrasi, media merupakan stimulator bagi terciptanya civic 
society, yang mengemban tugas memperluas peran warga negara dalam proses pengambilan keputusan dan partisipasi politik. Media juga dipandang memainkan peranan yang signifikan dalam mengantisipasi terjadinya otoritarianisme. Seperti yang diungkapkan oleh Per Bylund berikut ini,

In a democracy, the media, closely connected to generally advocated "free speech" concept, symbolizes and embodies the source of critical control of government and limitation of bad poltics. The left and the right both agree on the role of media in modern democracy; it has the power to control government. They agree the media is getting stronger and that politics depends on the media and in cherishing public relations via journalists to succeed. (http:www.strike-the-root.com/4/ bylund/bylund6.html, akses tanggal 13 Oktober 2009).

Senada dengan Per Bylund, Eric Louw juga mengungkapkan posisi sentral media sebagai sumber kekuasaan. Kekuasaan atau power dilihat sebagai kapasitas seseorang dengan caranya berinteraksi dengan orang lain. Kekuasaan ini mempengaruhi status sosial seseorang untuk pencapaian sebuah posisi dalam masyarakat. Secara eksplisit Eric Louw memaparkan, $(2005 ; 25)$

The media became the most important cultural resource during the twentieth century because it was the central site for impression management and defining social position and status.

Munculnya para konsultan politik di Indonesia dewasa ini yang berperan menciptakan pembentukan image bagi para kandidat politik untuk memikat konstituennya merupakan fenomena yang menarik. Menjadi lebih substansif apabila dikaitkan dengan peran media dalam penciptaan image tersebut. Membanjirnya iklan-iklan politik menjelang Pemilihan Presiden, Legislatif maupun Pemilihan Kepala Daerah yang notabene difungsikan untuk mendongkrak image para kandidat menjadi bukti empiris 'keterlibatan' mesin pembuat diskursus pencitraan.

T. Yulianti dalam tulisannya "President for Sale" mengungkapkan bahwa perkembangan demokrasi di tanah air memasuki era baru yang ditandai dengan kebangkitan para media stategi, image makers, dan konsultan politik di belakang tim sukses kampanye para calon presiden. Indonesia telah memasuki era "President for Sale" di mana kemenangan kandidat dalam Pemilu akan sangat ditentukan oleh kepiawaian konsultan politik dan biro iklan dalam menjual isu, image, dan janji-janji politisi yang menjadi kliennya (Suara Pembaharuan, 10 Juni 2004).

Citra merupakan ranah kehumasan dalam kajian Public Relations (PR). Pembentukan citra dalam skala korporat merupakan orientasi PR untuk memperoleh opini publik yang positif yang nantinya membawa reputasi sebuah organisasi. Al Ries menyatakan bahwa pembentukan citra merupakan aktivitas PR untuk membentuk serta mempengaruhi opini publik (battle of opinion).

Dalam hal ini, Al Ries menggambarkan proses pembentukkan opini publik layaknya sebuah pertarungan antar pihak-pihak yang bertikai. Pemenangnya ialah mereka yang mampu mengkontrol opini publik sesuai dengan tujuan yang diharapkan. Elizabeth Noelle Neumann, seorang ilmuwan politik dari Jerman dalam teori Spiral of the Silence Theory juga menguatkan kekuatan media sebagai pembentuk opini yang efektif untuk mempengaruhi publik. Demikian pula dalam 
ilmu marketing atau pemasaran, citra yang positif pada akhirnya diharapkan mampu memelihara loyalitas konsumen terhadap produk.

Di tanah air, tumbuhnya Pemilu sebagai sebuah industri juga kian jelas. Antara lain melalui munculnya lembaga-lembaga profesional non-partisan yang menyediakan jasa kampanye, keterlibatan banyak pakar ilmu komunikasi, promosi dan pemasaran, periklanan, dan public relations, sebagai tenaga profesional nonpartisipan dalam lembaga-lembaga penyedia jasa ataupun sebagai konsultan dari berbagai tim kampanye partai politik, calon presiden, atau calon anggota legislatif (Danial, 2009, xxv). Pada tahun 2009 saja, menjelang Pemilihan Legislatif sejumlah partai menghabiskan anggaran milyaran rupiah untuk beriklan di media baik cetak maupun elektronik.

Senior Manager Business Development Media ABG Nielsen Maika Randini mengatakan, hingga kuartal I 2009, belanja iklan partai politik melambung menjauhi iklan-iklan besar seperti telekomunikasi. Partai Golkar disebut sebagai penyumbang iklan tertinggi sebesar Rp. 128 miliar, diikuti Partai Demokrat Rp. 61 miliar (www.tribunkaltim.co.id/read/artikel/28272). Selain itu, partai yang juga gencar membombardir media ialah Partai Gerindra, Partai Kesejahteraan Sosial maupun Partai Demokrasi Pembangunan Indonesia.

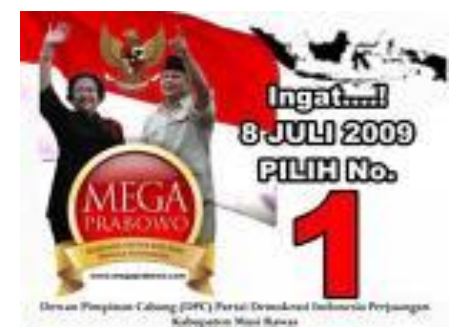

Sumber: images.google.co.id
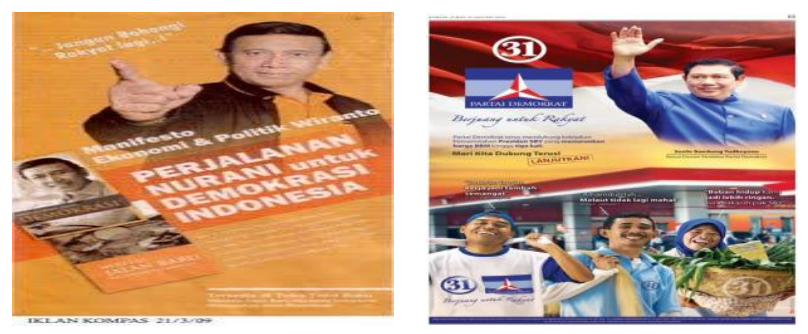

Gambar 1. Iklan Para Politisi Menjelang Pemilu

Kandidat politik dalam ranah citra direpresentasikan sebagai produk nomor satu, yang tiada duanya bagi publik. Seperti yang sudah diungkapkan di atas bahwa pertarungan atau kompetisi yang dilakukan oleh para kandidat tidak sebatas dalam ranah politik namun sudah mengalami pergeseran, yakni the battle of image. Di Amerika sebagai barometer demokrasi, pembuatan citra bagi para kandidat politik merupakan perkara yang strategis pada masa Pemilu.

Dalam komunikasi politik, citra tidak sekedar retorika saja atau bahasa verbal yang dikemukakan oleh para kandidat dalam kampanye. Citra juga menyangkut kecakapan non-verbal kandidat memikat dan menarik perhatian konstituennya. Shea dan Burton menangkap fenomena ini yang terlebih dahulu telah berkembang dalam pemilihan presiden Amerika menyatakan,

Candidates and their consultants understand the importance of a good picture and a powerful image. Candidates think visually and strategically construct events to create the most powerful pictures that support the politician's goals, whether that is to get on the nightly news or appear as a strong leader (Dan Schill, 
Finding a Place for Visual Communication in The Study of Political Communication, 2008).

Sama halnya yang terjadi di tanah air dewasa ini. Ketika politik mengalami pergeseran substansi, tidak berfokus pada esensi-esensi yang pernah menjadi isue yang diperjuangkan dalam politik tradisional. Politik dan citra dalam politik kontemporer menjadi bertautan, tali temali yang saling bersinergi. Media dalam hal ini menjadi agen yang efektif untuk menyebarkan politik citra tersebut. Dalam tulisan ini, penulis akan menguraikan politik citra dan kaitannya media sebagai perangkat image builder dalam dinamika politik Indonesia kontemporer. Penulis berharap di kemudian hari, akan ada tulisan serupa yang memberi rekomendasi mengenai obyektivitas media terkait dengan politik citra yang tidak dibahas dalam tulisan ini.

\section{PEMBAHASAN}

\section{Kandidat Politik dan Fenomena Hype}

Politik kontemporer yang disertai dengan modernisasi berdampak pada sistem politik. Swanson dan Mancini menyatakan bahwa konsekuensi yang muncul adalah "deideologisasi partai-partai politik" dan fenomena electoral parties yaitu partai-partai hanya bertujuan untuk memperbesar perolehan suara dalam Pemilu dan membicarakan banyak isu tanpa mempertimbangkan ideologi (dalam Danial, 2005 : $55)$.

Dalam politik Indonesia kontemporer, tidak banyak partai politik yang memiliki komitmen yang tinggi terhadap ideologi partai serta rekruitmen yang khusus dan seleksi yang ketat terhadap kader-kadernya. Berbeda dengan wajah politik Indonesia pada Orde Lama maupun Orde Baru yang mengedepankan perilaku doktriner partai politik. Selama kampanye, program-program yang ditawarkan kepada masyarakat lebih bersifat generik, tidak banyak partai politik yang menawarkan program yang berbeda dengan program partai lainnya. Program nasional menjadi seragam dan partai politik menjadi kehilangan kekhasannya dan karakteristik perjuangannya.

Dalam kondisi seperti ini, partai politik melemah dan kemudian melahirkan personifikasi yang dipandang sebagai representasi bagi ide-ide politik yang masih baru dan segar sehingga keberadaan partai politik terabaikan. Perolehan suara pada akhirnya tidak saja ditentukan oleh elektabilitas namun popularitas yang dimiliki oleh kandidat. Popularitas ini menuntut para kandidat untuk menampilkan identitasnya selaras dengan 'selera publik'. Eric Louw (2005) memperkenalkannya dengan istilah yang disebut hype, yang secara harfiah dimaknai sebagai sesuatu yang sifatnya melebih-lebihkan.

Berpijak pada fenomena di Indonesia saat ini, pemilu tidak ubahnya sebagai kontestasi kharisma dan pesona para kandidat dalam mengikat konstituennya. Sebagaimana layaknya sebuah produk yang akan dipasarkan, kandidat politik juga harus mempunyai ketrampilan mengemas identitas menjadi citra yang diharapkan oleh konstituen.

Maraknya konsultan politik menjelang kampanye pada Pemilu 2009, merupakan indikasi bahwa pencitraan menjadi the prime need bagi para politisi 
untuk menjaring dan memikat pemilih. Presiden Indonesia terpilih untuk periode 2009-2013, Susilo Bambang Yudhoyono(SBY) misalnya, bersama dengan partai Demokrat mempercayakan Fox Foundation, sebuah konsultan politik yang dimotorti oleh Rizal Malarangeng sebagai image maker.

Harian Kompas memberitakan, ketiga pasangan kandidat presiden dan wakil presiden diperkirakan telah mengeluarkan sekitar Rp. 3 triliun untuk kampanye di media massa. Jika pemilu presiden berlangsung dua putaran tentu belanja kampanye ini akan membesar lagi. Konsultan politik disewa kandidat dengan tujuan membantu untuk memenangkan pemilihan. Kepentingan yang selaras antara konsultan dan kandidat ini tidak otomatis terjadi, Sebagai bisnis, tujuan utama konsultan adalah mendapatkan profit dan ini tidak selalu selaras dengan kepentingan kandidat yang ingin menang (Roby Muhamad, Bisnis Konsultan Politik, http://pemilu.liputan6.com/kolom/200906/234428/Bisnis.Konsultan.Politik).

Eric Louw (2005: 21) memaparkan bahwa ada tiga dimensi politik yang berlangsung dewasa ini yakni pertama ialah politik yang dimainkan oleh para elit yang bekerja dalam ranah subtansi, menghasilkan output politik seperti produk berikut : kebijakan nasional maupun internasional, per UU, memperjuangkan kepentingan antar kelompok, dsb. Pada konteks ini, politik dikendalikan oleh birokrasi, kabinet, judiciary serta para intelektual dan ahli lobby politik.

Pada level yang ke dua, politik tetap menjadi milik kaum elit namun terjadi pergeseran output yaitu berupa perencanaan dan koordinasi yang dijewantahkan dalam bentuk menetapkan ideologi dan nilai-nilai yang akan dipercayai bersama, merumuskan identitas, menyeleksi politisi berikut stafnya serta menetapkan strategi yang menyangkut kebijakan, hype maupun relasi antara kebijakan dan hype.

Selanjutnya, Eric juga memaparkan tentang mass politics, yang menggambarkan politik sebagai arena bagi image and myth making to be consumed by voters. Mass politics ini dikendalikan oleh para aktor seperti jurnalis, industri budaya dan pundits. Pada tataran ini, outout politik diharapkan menghasilkan pencitraan yang kemudian ditandai dengan performance kandidat sebagaimana seorang selebriti. Dalam hal ini, identitas sang kandidat diciptakan untuk kemudian dikonsumsi.

Fenomena hype pada politik Indonesia dewasa ini menuntut penggunaan teknik-teknik khusus untuk mengangkat popularitas dan mendongkrak citra kandidat. Teknik-teknik public relations sekaligus marketing ini mengarahkan setiap kandidat untuk memiliki kemampuan seperti selebritis yang kehadiran serta berita yang menyangkut dirinya dinantikan oleh jutaan masyarakat dengan harapan mendapatkan up dating information bagi pencerahan masa depan bangsa.

Seorang selebritis akan menarik perhatian apabila tampil semenarik mungkin di depan publik. Baik tutur kata maupun penampilan. Performance-nya menjadi memikat ketika sang selebritis memadukan kecakapan verbal maupun nonverbalnya termasuk daya tarik fisik. Hal ini terjadi pula ketika masa kampanye, keahlian para tokoh dan partai politik mengemas identitas mereka menjadi persoalan yang signifikan.

Dalam komunikasi politik, dikenal istilah spin doctor atau staf ahli yang menjadi "juru rias" para kandidat dalam masa kampanye politik. Dalam kenyataannya, spin doctor memang tidak selalu berhasil membawa kemenangan bagi kandidat politik namun tidak bisa dipungkiri bahwa keberhasilan seorang kandidat dalam pertarungan politik juga disebabkan oleh spin doctor tersebut. Istilah spin doctor merupakan istilah baru dalam komunikasi politik yang diperkenalkan oleh tim 
kampanye Ronald Reagen sekitar tahun 1984 menggantikan istilah konsultan public relations politik. McNair dalam bukunya An Introduction to Political Communication (1999) mendefinisikan spin doctor sebagai individu yang memiliki kemampuan menguasai publik, menggerakkan massa dan menguasai media, sekaligus sebagai konseptor politik yang bertujuan memengaruhi.

Di Amerika, konsultan politik atau yang lebih dikenal dengan press agentry merupakan profesi yang telah lama berkembang sejak tahun 1930-an. Adalah sepasang suami istri, Cleam Whitaker dan Leon Baxier di Los Angeles yang menggagasnya dengan bendera Campaign Inc. Konsultan politik bertugas selayaknya seorang public relations (PR) dan marketer yang merumuskan strategi untuk mendongkrak citra sekaligus memasarkan identitas sang kandidat dan menegasi rival atau lawan politiknya. Artinya, sedari awal para konsultan politik menyadari misi mereka sebagai agen yang bertugas membangun image politik serta di sisi yang lain, mengemban tugas untuk memberikan kesan negatif pada saingan politik kleinnya.

Istilah spin doctor memang tidak populer di Indonesia. Masyarakat umum dan di kalangan partai politik lebih mengenalnya dengan sebutan tim sukses, konsultan politik atau manajer kampanye. Dengan menggunakan media komunikasi dalam pembentukan opini publik tersebut, spin doctor sesungguhnya tengah merekayasa cara-cara pemaksaan dalam kampanye menjadi sebuah bujukan (Etman dalam Louw, 2005). Kampanye kemudian berubah menjadi ajang bagi para kandidat untuk memainkan drama sebaik mungkin. Isu yang berkembang didramatisasi sehingga menimbulkan kesan pencapaian-pencapaian yang telah diraih oleh sang kandidat.

Program BLT atau Bantuan Langsung Tunai misalnya yang disinyalir berhasil membawa kemenangan bagi partai Demokrat dalam pemilu 2009 lalu. Dalam beberapa kesempatan selama kampanye, Bambang Susilo Yudhoyono seringkali menyinggung bahwa BLT ini merupakan program populer di banyak negara berkembang, tidak hanya di Indonesia saja. Program ini dilihat sebagai bentuk pertanggungjawaban pemerintah terhadap masyarakat ekonomi lemah. Di satu kesempatan lain, PDIP menyatakan bahwa embrio program tersebut telah ada sejak pemerintahan Megawati. Di sinilah terjadi perang opini. Kelihaian spin doctor dalam mengemas kiprah kliennya menentukan opini publik. Terlepas dari siapa yang benar atau pihak mana yang keliru.

Dalam hal inilah, spin doctor tidak hanya berperan sebagai jembatan yang menghubungkan parpol dengan media saja. Spin doctor memiliki peran yang sangat penting dan menentukan posisi kandidat dalam kancah pertarungan kekuasaan politik. Di Indonesia, selama beberapa tahun terakhir ini, partai dan kandidat politik disuguhi banyak konsultan politik yang bertindak sebagai spin doctor. Misalnya saja Fox Indonesia, Lembaga Survei Indonesia, Lingkaran Survei Indonesia, P2P LIPI, Reform Institute dan lainnya yang menawarkan strategi perancangan serta penciptaan image.

\section{Konstituen sebagai Target Pasar Politik}

Seperti yang telah dipaparkan pada bagian sebelumnya, fenomena hype menggiring politik Indonesia kontemporer masuk dalam sebuah era yang disebut 
opini publik atau public opinion. Firmanzah dalam Marketing Politik ${ }^{1}$ menjelaskan public opinion era ini menjadi salah satu karakteristik fenomena politik di Indonesia. Opini publik ini pula yang selalu menjadi pusat perhatian lembaga-lembaga survei serta para konsultan politik ketika menjelang Pemilu.

Pada umumnya, yang ingin diketahui pertama kali oleh mereka adalah tingkat popularitas dan selanjutnya tingkat elektabilitas kliennya. Proyek politik ini diawali dengan survey dan riset pasar untuk mengukur perilaku politik konstituen. Riset pasar terhadap tokoh politik ini dilakukan seperti layaknya riset pasar sebuah produk atau jasa. Riset pasar sendiri merupakan aktivitas yang identik dengan aktivitas pemasaran. Kotler memberi definisi pemasaran sebagai berikut ini: " $A$ societal process by which individual and groups abtains what they need and want through creating offering, and freely exchanging product and value with others" (dalam Kennedy dan Soemanagara, 2006: 3).

Penggunaan metode marketing dalam bidang politik dikenal sebagai marketing politik (political marketing). Dalam marketing politik, yang ditekankan adalah penggunaan pendekatan dan metode marketing untuk membantu politikus dan partai politik agar lebih efisien serta efektif dalam membangun hubungan dua arah dengan konstituen dan masyarakat.(Firmanzah, 2008: 128)

Seperti halnya marketer, spin doctor ini juga bertugas mengamati tren dan kecenderungan konstituen mengalokasikan suaranya dalam Pemilu. Temuannya akan sangat bermanfaat untuk merumuskan strategi perancangan aktivitas public relations, marketing serta advertising bagi kandidat atau kliennya. Mengenai hal tersebut Butler dan Kavanagh menjelaskannya seperti berikut ini,

"More than ever, election campaigns are managed and orchestrated. Each party attempts to shape the agenda so that the media reflects its views on favourite issue. Public opinion is monitored through opinion polls. An election campaign is increasingly seen by those in charge as an exercise in marketing and many of the skills of selling goods and services to customers are now applied to the electorate. These developments have given greater scope to experts in opinion polling, advertising and public relations, and sometimes lead to tensions with the politicians and party offices."(dalam McNair, 1999)

Dalam komunikasi politik, opini publik ini memainkan peranan yang signifikan khususnya menjelang kampanye. Dan Nimmo (2000) memaparkan opini publik sebagai gejala yang multidimensional yang diterbentuk karena adanya saling mempengaruhi di antara proses personal, sosial dan politik. Jauh sebelum masa kampanye, biasanya manajer kampanyr atau konsultan politik akan melakukan jejak pendapat untuk mengukur opini serta menampilkan hasil survey terbaru terkait dengan tingkat popularitas kliennya.

Teknik-teknik pemasaran dan upaya pencitraan yang dilakukan oleh konsultan politik bagi politisi tak ubahnya ketika memasarkan produk kepada publik. Aspek emosional akan menjadi tujuan utama para konsultan politik untuk memikat dan mempersuasi publik daripada memaparkan secara jelas mengenai ideologi partai, program kerja partai politik ataupun yang terkait visi-misi partai politik. Konsultan

${ }^{1}$ Bahan ajar dalam Pasca Sarjana Ilmu Manajemen Universitas Indonesia, sumber: forumpolitisi.org/downloads/Marketing_Politik_Firmanzah.pdf. 
politik juga harus memonitor aktivitas lawan politik kliennya. Sama halnya dengan sebuah produk, kompetitor tidak akan dibiarkan menguasai pasar secara tunggal.

Swanson mengidentifisikan adanya perubahan hubungan antara pemilih dan partai politik di mana sekarang ini hubungan pemilih dengan partai tidak lagi berdasarkan identitas sosial serta komitmen jangka panjang si pemilih. Di era modern, hubungan pemilih dengan partai lebih didasarkan oleh persuasi yang dilakukan partai terhadap pemilih untuk memilih kandidat atau partai politik tertentu hanya pada saat Pemilu saja (dalam Danial, 2009; 57).

Posisi konstituen dalam politik Indonesia kontemporer menjadi sama dengan target pasar. Dalam mengkomunikasikan pesannya, tokoh dan partai politik harus memperhatikan konten sesuai dengan sasaran pesan tersebut. Iklan Prabowo Subianto misalnya, sangat memikat dan menarik para pekerja di sektor agraris. Ajakannya untuk minum susu dan memakai produk nasional menarik simpati banyak UKM di Indonesia. Demikian halnya ketika ia menyadarkan nasib para petani sebagai 'tulang punggung' perekonomian nasional.

Hal yang sama ketika SBY akan mencalonkan kembali dalam Pemilu 2009. Iklan SBY terkait dengan penurunan harga BBM dinilai oleh lawan politiknya sebagai upaya untuk mencari simpati dan popularitas saja. PDIP sebagai oposisi mengcounternya dengan mengadakan jumpa pers yang menyatakan bahwa di tahun 2004, ketika minyak dunia sekitar US\$36,05, harga BBM Rp. 1.955. Kini minyak bumi dunia pasarannya US\$ 40, tapi harga BBM di Indonesia walaupun turun menjadi Rp. 4.500, jadi masih jauh lebih mahal dibanding harga di tahun 2004. (Sumber: www.detiknews.com/read/2009/01/22). Jadi, sesungguhnya pemerintahan SBY gagal membuat harga minyak menjadi lebih murah bagi masyarakat. Pesan iklan SBY seolah menjadi paradoks ketika iklan Megawati dan Wiranto menggambarkan kondisi dan nasib bangsa yang tidak mengalami perubahan. Di sinilah, manuver pemasaran dimainkan, ketika harga BBM menjadi isue yang vital bagi target pasar politik baik dari kalangan wong cilik, profesional sampai pengusaha.

\section{Media dan Politik Citra}

Media khususnya televisi merupakan saluran yang efektif untuk menyebarkan dan membangun sebuah citra bagi kandidat politik. Menurut Holtz-Bacha dan Kaid (dalam Danial, 2009, 93) televisi digunakan oleh partai politik dan kandidat setidaknya melalui dua cara. Pertama, lewat "cara-cara gratis" melalui peliputan reguler media terhadap kegiatan partai atau kandidat politik. Dalam peliputan bebas itu, berlaku prinsip-prinsip seleksi jurnalistik dan kriteria produksi yang biasa digunakan oleh para jurnalis dan pengelola televisi. Aktor politik tidak bisa mempengaruhi kapan, seberapa panjang, dan bagaimana peristiwa politik itu diliput media.

Kedua, membayar ke media tersebut karena memasang "iklan politik" (political advertising). Dalam iklan politik, kandidat atau partai politiklah yang memutuskan bagaimana mereka ditampilkan di hadapan pemilih.Karena itulah, dua bentuk penggunaan media televisi itu (free and paid media) sering juga diistilahkan dengan controlled media dan uncontrolled media. 
Politisi dan partai bisa mengontrol isi pesan politik yang disampaikan dalam iklan politik, namun tidak mempunyai kontrol terhadap bagaimana media mengemas berita-berita politik di televisi. Demikian halnya dengan Robert Denton, Nimmo dan Flesberg (dalam Brian McNair, 1999) juga mengungkapkan pernyataan serupa bahwa televisi merupakan media utama yang banyak digunakan oleh para kandidat politik dalam pemilu. "Paid political advertising via television now constituates the mainstream of modern electoral politics"

Permasalahan akan menjadi kompleks apabila pemilik media masuk dalam pusaran kekuasaan sehingga mau atau tidak, isi media menjadi bagian dari konstruksi untuk memperluas pengaruh dan berperan sebagai image making machine. Di Indonesia, kepemilikkan media televisi misalnya, mayoritas berada di tangan aktor-aktor politik yang notabene memiliki kapital yang besar. Pemberitaanpemberitaan yang diproduksi oleh media pun kemudian akan disesuaikan dengan 'taste' dan kepentingan pencitraan dari sang pemiliknya.

Misalnya saja yang ramai diperbincangkan oleh kalangan intelektual dan pemerhati media mengenai kasus Munas Golkar. Bagaimana ANTV dan TVOne terus membombardir pemirsa dengan iklan yang menyuguhkan profil dan kiprah Aburizal Bakrie sebagai calon ketua Golkar. Manuver Surya Paloh juga tidak ketinggalan sebagai pemilik televisi MetroTV. Sebagai rival, Surya Paloh secara agresif pula menggunakan medianya untuk 'memasarkan' dirinya maju sebagai ketua umum Golkar.

Pada masa Orde Baru, ketika dilaksanakan pemilu pada tahun 1977, media massa saat itu yang banyak digunakan sebagai image manufacturing ialah printed media. Pembaca dari beberapa media merupakan konstituen loyal terhadap salah satu partai. Misalnya Harian Pelita yang banyak dibaca dan dikhususkan untuk pemilih PPP, begitu pula dengan Harian Merdeka yang pembacanya merupakan konstituen PDI. TVRI sebagai satu-satunya stasiun televisi pada era itu banyak dimanfaatkan oleh Golkar sebagai partai penguasa.

Secara historis, modernisasi komunikasi politik yang melibatkan media massa sebenarnya sejak tahun 1982 telah dilakukan di Indonesia. Hanya saja belum sespektakuler pada era reformasi yang mengaitkannya dengan citra serta brand personal. Kala itu Emil Salim selaku Menteri Lingkungan Hidup telah menggunakan praktik-praktik kehumasan untuk efektivitas kampanyenya. Apa yang dilakukan oleh Emil Salim tersebut membawa pembaharuan bagi gaya kampanye yang berbeda dengan gaya kampanye yang penuh intimidasi dan rekayasa ala Orde Baru. (Danial, 2009, 122)

Iklan pertama kali yang muncul pasca lengsernya regim Orde Baru ialah iklan PKB pada tahun 1998 yang memboyong Abdurrahman Wahid sebagai tokohnya. Sebagai negarawan yang notabene handicapped, Matari Inc., sebuah perusahaan periklanan besar memberinya tajuk 'Saya Mendengar Indonesia Menyanyi” untuk iklan tersebut. Berikut kutipan iklannya: "Saya boleh saja dianggap tidak bisa melihat dengan baik, akan tetapi saya dapat mendengar, mendengar dengan baik Indonesia kita menyanyi. Menyanyikan harapan, pengabdian dan perjuangan" (Danial, 173)

Iklan politik pertama dalam sejarah Pemilu di Indonesia itu, selain dimuat di televisi, juga dimuat dalam versi cetak di berbagai media cetak, seperti Majalah Ummat, Panji Masyarakat, Gatra, Harian Kompas, Media Indonesia, Suara 
Pembaruan, Republika, Bisnis Indonesia, Suara Merdeka (Semarang), Pikiran Rakyat (Bandung), Singgalang (Padang), dan Tabloid Realitas.(Bersiap Menangguk Iklan Partai, Majalah Cakram edisi Februari 1999 dalam Danial, 2009)

Pencitraan kandidat melalui media khususnya pada televisi memang menjadi tren kurang lebih satu dasawarsa terakhir. Fenomena ini menyertai terjadinya era reformasi di Indonesia yang membawa euforia bagi demokratisasi. Begitu pula dengan iklan-iklan yang terpampang secara on line di beberapa portal nasional. Sebagai aktivitas promosi, Iklan di media, apakah itu dilakukan oleh korporat atau personal merupakan investasi yang tidak murah.

Politik citra 'berbicara' tidak sekedar persoalan kemampuan finansial kandidat politik membayar biaya iklan. Politik citra juga meliputi konstruksi-konstruksi pemberitaan media terhadap kandidat serta kelanggengan sebuah regim. Secara eksplisit McNair mengungkapkannya seperti berikut ini,

"Not only do the media report politics, they are a crucial part of the environment in which politics is pursued. They contribute to policy discussion and resolution, not only in so far as they set public agendas, or provide platforms for politicians to make their views known to public, but also in judging and critiquing the variety of political viewpoints in circulation." (1999; 73)

Dalam sejarah perkembangan media di Indonesia, mencatat TVRI sebagai public media seringkali dimanfaatkan sebagai corong Orde Baru untuk menonjolkan keberhasilan program pembangunan yang pada akhirnya mengarah pada pengkultusan satu orang tokoh politik. Pemberitaan-pemberitaan seputar Pemilu menjadi tidak berimbang dan cenderung memberi porsi lebih banyak terhadap partai tertentu.

Kembali ke masalah Munas Golkar, MetroTV melalui program features-nya, Kick Andy 'membantai' habis Aburizal Bakrie sebagai aktor dibalik kasus lumpur Lapindo-Sidoarjo. Dalam beberapa segmennya, Kick Andy menghadirkan testimoni korban lumpur yang memaparkan kesusahan hidup akibat seluruh harta bendanya terendam lumpur. Bahkan, ada narasumber yang secara eksplisit 'mengutuki' Aburizal Bakrie. Tayangan ini tentunya berbeda dengan yang disajikan oleh TV One dalam program talk show-nya Selamat Malam Indonesia yang pada suatu edisi menghadirkan beberapa narasumber yang sangat apresiatif terhadap pengalaman organisasi serta komitmen Aburizal Bakrie terhadap permasalahan-permasalahan sosial. Inilah yang terjadi, esensi demokrasi telah bergeser dan menjadi jelas bahwa politik Indonesia kontemporer membutuhkan industri media sebagai image making machine.

\section{KESIMPULAN}

Era opini publik menandai politik Indonesia kontemporer. Opini publik tersebut menggiring peranan media dalam kaitannya dengan pencitraan kandidat politik. Pengaruh media atas opini publik menjadi semakin pelik ketika industri media terkait dengan lingkaran kekuasan serta pemilik modal. Sebagai sebuah industri budaya, media melanggengkan fenomena hype. Sebagai image making machine, 
media berkolaborasi dengan para spin doctor untuk mencetak kandidat politik sebagai komoditas.

Bagaimanakah masa depan obyektivitas media terkait dengan politik citra ?. Dalam pemberitaan, obyektivitas media secara optimis masih bisa diupayakan. Berbeda halnya ketika berbicara tentang iklan, obyektivitas media hanya akan menjadi wacana saja. Maraknya iklan politik dalam tayangan televisi Indonesia menjelang pemilu menjadi bukti bahwa faktor ekonomis menjadi prioritas bagi media. Iklan politik menyangkut tentang uang yang berarti bagi kelangsungan hidup media. Semakin banyak iklan yang masuk semakin besar profit yang diperoleh. Tingkat kekuatan politik citra di media tergantung pada sikap kritis konstituen sebagai khalayak sasaran serta independensi organisasi media.

\section{DAFTARPUSTAKA}

Danial, Akhmad. 2009. Iklan Politik TV: Modernisasi Kampanye Politik Pasca Orde Baru, LKIS.

Firmanzah. 2009. Marketing Politik: Antara Pemahaman dan Realitas, Yayasan Obor Indonesia.

Kennedy dan Soemanagara, John E \& R. Dermawan. 2006. Marketing Communication: Taktik \& Strategi, PT. Bhuana Ilmu Populer.

Louw, Eric. 2005. The Media and Political Process, Sage.

McNair, Brian. 1999. An Introduction to Political Communication, Routledge.

Nimmo, Dan. 2000. Komunikasi Politik: Khalayak dan Efek, PT. Remaja Rosdakarya.

Schill, Dan. 2008. Finding a Place for Visual Communication in The Study of Political Communication.

http:www.strike-the-root.com, akses tanggal 13 Oktober 2009.

http://pemilu.liputan6.com, akses tanggal 13 Oktober 2009.

www.tribunkaltim.co.id/read/artikel/28272, akses tanggal 27 Januari 2010.

forum-politisi.org, akses tanggal 25 Januari 2010.

www.detiknews.com, akses tanggal 26 Januari 2010.

Suara Pembaharuan, 10 Juni 2004. 